DOI

\title{
РОЛЬ ПЕДАГОГІЧНОГО СПІЛКУВАННЯ МІЖ ВИКЛАДАЧАМИ ТА СЛУХАЧАМИ КУРСІВ ПІСЛЯДИПЛОМНОЇ ПІДГОТОВКИ 3 ТЕРАПІЇ ТА ГАСТРОЕНТЕРОЛОГІЇ В ОПТИМІЗАЦІЇ НАВЧАЛЬНОГО ПРОЦЕСУ
}

\author{
Ю. М. Степанов, І. М. Кононов, І. Я. Будзак, С. В. Косинська, А. В. Саленко \\ Державний заклад “Дніпропетровська медична академія МОЗ України”
}

\section{ROLE OF PEDAGOGICAL COMMUNICATION BETWEEN TEACHERS AND STUDENTS OF POST-GRADUATE TRAINING IN INTERNAL MEDICINE AND GASTROENTEROLOGY IN THE OPTIMIZATION OF THE EDUCATIONAL PROCESS}

\author{
Yu. M. Stepanov, I. M. Kononov, I. Ya. Budzak, S. V. Kosynska, A. V. Salenko \\ State Establishment "Dnipropetrovsk Medical Academy of MPH of Ukraine”
}

\begin{abstract}
Стаття присвячена питанням психології взаємовідносин між викладачем та лікарями, що проходять післядипломне навчання. Розглянуті чотири типи взаємовідносин між викладачем і слухачем. Наголошено на важливості досягнення авторитету викладача в очах слухачів. Також у статті показані стилі педагогічного спілкування між викладачем і слухачем. Окремо описані дидактичні принципи навчального процесу.

The article is devoted to the psychology of relationships between teacher and doctors undergoing post-graduate training. We consider four types of relationships between the teacher and the listener. It is noted the importance of achieving the authority of the teacher in the eyes of the listeners. The article also shows the styles of pedagogical communication between the teacher and the listener. Separately, there are described the didactic principles of the educational process.
\end{abstract}

Вступ. Відомо, що низька ефективність навчання часто буває пов'язана з особливими реакціями особистості та типом взаємодії між викладачем та тим, хто навчається. Саме спілкування між тими, хто бере участь у навчальному процесі, є дуже складним поняттям. Ця категорія складається з професійного спілкування, яке спрямовано на розширення професійного кругозору та інтелектуального потенціалу, оновлення знань, вмінь та практичних навичок і створення сприятливого клімату для психологічної оптимізації навчальної діяльності.

Якість післядипломної підготовки лікарів 3 терапії та гастроентерології в сучасних умовах визначається не тільки рівнем знань на курсах підвищення кваліфікації, але і професійними рівнями, що дозволяють творчо вирішувати виникаючі проблеми, активно взаємодіяти 3 хворими і колегами по роботі на основі встановлення суб’єктивних відносин.

() Ю. М. Степанов, І. М. Кононов, І. Я. Будзак та ін.
Основна частина. Однією з найважливіших умов підвищення ефективності навчального процесу $є$ взаємодія, яка складається між викладачем і курсантом. Взаємодія в системі “викладач - слухач курсів удосконалення терапії та гастроентерології” має велике переважне значення з точки зору взаємозв'язку між соціальними, культурними чинниками, структурою особистості, оскільки ці відносини впливають на формування системи цінностей лікаря будь-якої спеціальності. Процес взаємодії викладача і слухача курсів перебігає в зіткненні інтересів, життєвих позицій, мотивів, особистого індивідуального досвіду, що впливає на формування взаємин між ними в ході навчального процесу.

Навчальний процес - це спільна діяльність викладача і курсанта, що спрямована на забезпечення навчання. У цьому процесі існуючу роль відіграє проблема взаємовідносин між учасниками процесу навчальної діяльності.

Існують чотири типи взаємовідносин між викладачем і курсантом: 1) командний - коли викладач 
ставить себе на п’єдестал, командує, як навчатися. Тут домінує єдиноначальність; 2) демократичний - коли викладач виступає як співучасник у діяльності з курсантом, керує і допомагає йому; 3) ліберальний - відсутня активна участь викладача в управлінні навчального процесу; 4) тип потурання - характеризується “байдужістю” з боку викладача щодо розвитку та динаміки навчальних досягнень курсантів.

Колективна робота передбачає взаємодію не тільки в аспекті викладач - курсант, але і в колективі курсантів між собою, навчання співпраці, роботу в колективі. Найважливіша роль викладача - забезпечення навчальної діяльності курсантів. На ставлення викладача і курсанта в кожному конкретному випадку впливає багато факторів: соціальнопсихологічна обстановка в суспільстві, економічні умови, рівень суспільної культури, професійна підготовка, моральність, стиль спілкування і багато інших складових. На сучасному етапі різко зростає роль викладача в роботі з курсантами на факультеті післядипломної освіти, розширюється діапазон його психологічного та педагогічного впливу на курсантів. Викладач вже не може бути лише провідником знань та інформації, він повинен бути педагогом, психологом, артистом, психотерапевтом. Від цього багато в чому залежить успішність його педагогічної діяльності і авторитет.

Авторитет викладача - інтегральна характеристика його професійної, педагогічної та особистісної позиції в колективі, яка виявляється в ході взаємин 3 колегами, курсантами і впливає на успішність навчального процесу. Авторитет викладача будується на двох складових - авторитету ролі і авторитету особистості. Сьогодні на перший план вийшла друга складова авторитету викладача - це особистість викладача, його яскрава індивідуальність, яка має на курсантів не тільки педагогічний, але і психотерапевтичний вплив.

Три типи педагогічних умінь формують авторитет викладача: 1) наукові знання; 2) знання про своїх курсантів і колег; 3) знання про самого себе та вміння корегувати свою поведінку.

Основні складові авторитетності особистості викладача: 1) співвідношення самооцінки викладача 3 оцінкою його особистості курсантами та колегами; 2) вміння сприймати і переробляти складну і суперечливу інформацію, знаходити гідний вихід 3 важкої педагогічної і життєвої ситуації.

Багаторічні наукові психологічні дослідження дозволили виділити особливості авторитетного і неавторитетного викладача. Авторитетні викладачі володіють високою педагогічною спостережливістю, повагою до курсантів, стимулюють їх активність й інтелектуальну діяльність, виявляють гнучкість і нестандартність у прийнятті педагогічних рішень, отримують задоволення від спілкування 3 курсантами. Неавторитетні викладачі застосовують жорсткі, авторитарні методи педагогічного спілкування, використовують комутативні стереотипи в процесі викладання, монологічність спілкування і невміння поважати курсантів незалежно від їх успіхів у навчанні.

Авторитетний викладач повинен володіти такими особистісними якостями, як: 1) професіоналізм і глибоке знання предмета; 2) вміння доступно викладати свої думки; 3) володіння високою загальною культурою і ерудицією, швидкістю реакції і мислення; 4) уміння відстоювати і захищати свою власну точку зору; 5) розуміння психології курсанта, його гідності і недоліків; 6) уважне ставлення до вивченого; 7) доброзичливість і терплячість; 8) строгість у поєднанні зі справедливістю; 9) психологічна стійкість і спритність у важких ситуаціях.

Важливу роль у роботі викладача відіграють його артистичні дані: вміти красиво говорити, вміти триматися на сцені, викликати позитивні емоції у слухачів, бути пунктуальним, під час роботи думати тільки про роботу, стежити за собою, виглядати охайно і гарно пахнути, дотримуватися правил пристойності і хорошого тону, не сумувати, бути люб’язним, ввічливим з усіма, не розслаблятися, бути організованим і дисциплінованим, постійно розвивати і вдосконалювати свої артистичні навички. 3 особистістю викладача несумісні такі характерологічні реакції, як грубість, недоброзичливість, самозакоханість, гіпертрофоване наставництво, сором'язливість, консерватизм, повільна реакція, прагнення пригнічувати особистість курсанта, незібраність, лінь, зайва емоційність, вибуховість, відсутність педагогічної майстерності. Викладач повинен вміти долати ці труднощі, тому що управління іншими починається з управління собою.

Поглиблені дослідження в галузі педагогічної психології показують, що багато труднощів у педагогіці пов’язані не тільки з недоліками наукової і методичної підготовки викладача, скільки з порушенням у середовищі професійно-педагогічного спілкування з курсантами і залежить від стилю керівництва викладача.

Відомий психолог В. О. Кан-Калик виділяє кілька стилів педагогічного спілкування між викладачем і слухачем: 1) спілкування на основі професійних 
установок педагога, де інтерес у спілкуванні стимулюється ще і спільними професійними інтересами; 2) спілкування на основі дружньої прихильності, яке передбачає захопленість спільною справою. Тут педагог є наставником, учасником спільної навчальної діяльності, але при цьому потрібно уникати панібратства; 3) спілкування-дистанція. Належить до найбільш поширених типів педагогічного спілкування. У всіх сферах, у навчанні простежується дистанція, з посиланням на авторитет і професіоналізм; 4) спілкування-залякування - негативна форма спілкування, антигуманна, розкриває педагогічну неспроможність викладача; 5) спілкування-загравання - характерно для молодих викладачів, які прагнуть популярності.

Таке спілкування забезпечує помилковий авторитет. У практиці викладання спостерігається поєднання різних стилів в тій чи іншій пропорції, коли один 3 них переважає. Давно помічено, що при однакових умовах викладачі з однаковою освітою і стажем вчать по-різному, і від одних і тих же курсантів домагається різних освітніх результатів.

В одних викладачів курсанти отримують такі бали і оцінки, які ніколи не отримають в іншого викладача, а у третього можуть вирішувати нестандартні складні завдання, вирішувати які не може ні перший, ні другий. У четвертого вони виходять творчими людьми і т. д.

Навчальний процес спирається на сукупність дидактичних принципів з використанням активних методів навчання і включає свої специфічні принципи: 1) рівноваги між змістом і методами навчання (з урахуванням підготовленості управління поведінкою курсанта і темою заняття); 2) моделювання. Зв’язок 3 навчальним планом, де відображені цілі, завдання, засоби і методи навчання, формуються запитання і завдання, які вирішуються у процесі навчання; 3) вхідного контролю, який передбачає підготовку навчального процесу згідно з реальним рівнем підготовки управління поведінкою курсантів, їх інтересів, потреб у вдосконаленні знань, умінь та практичних навичок і дає можливість визначити зміст, методи навчання, характер та обсяг індивідуальної роботи управління поведінкою курсантів; 4) відповідності змісту і методам навчання, що дозволяє вибрати оптимальні види навчальної діяльності для вивчення теми контрольної роботи або розв’язання ситуаційної задачі; 5) проблемності, що вводить управління поведінкою курсанта в проблемну ситуацію, для виходу з якої він змушений самостійно формувати нові знання, грунтую- чись на своєму і чужому досвіді, логіці і здоровому глузді; 6) “негативного досвіду”, який вчить управління поведінкою курсанта, уникати помилок. Для цього в навчальний процес вносяться: а) вивчення, аналіз і оцінка помилок, допущених у конкретних ситуаціях; б) моделюється ситуація, при якій курсант неминуче допускає помилку, джерелом якої є відсутність досвіду. Аналіз алгоритму дій курсанта допомагає виявити закономірності помилки і розробити тактику розв’язання ситуаційної задачі. При цьому курсант переконується в необхідності вдосконалення знань з цієї проблеми; 7) “від простого до складного”, передбачає облік навчального матеріалу і методів, використовуваних при його вивченні; 8) безперервного оновлення, який передбачає постійне оновлення методики навчання, нових технологій та інновацій у вивченні конкретної теми, що не дає притупити інтерес курсантів до досліджуваного об’єкта; 9) мотивації. Значення мотивації для успішного навчання вище, ніж значення інтелекту курсанта. Висока позитивна мотивація відіграє роль компенсуючого чинника у випадку недостатньо високих здібностей курсанта. Мотивом можуть бути і професійний інтерес, і творчий характер навчально-допоміжної діяльності, і змагальність, ігровий характер проведення занять; 10) економії навчального часу. Засвоєння знань, оволодіння практичними прийомами роботи, навичками і вміннями здійснюється одночасно, в одному процесі розв’язування ситуаційних задач, аналізу ситуацій або ділової гри; 11) вихідного контролю. Це іспит, залік, співбесіда, виконання контрольних робіт. У процесі навчання курсант здобуває знання, створює суб’єктивно новий або об’ єктивно новий продукт. Його діяльність здійснюється на репродуктивному і продуктивному рівнях. При здійсненні курсантами цих видів освітньої діяльності проявляються відповідні якості особистості. Виділяють когнітивні (пізнавальні), креативні (творчі) і оргдіяльні якості курсанта.

Креативні якості - це: 1) емоційно-образні якості: натхнення, уява, фантазія, асоціативність, мрійливість; 2) ініціативність, неординарність, нестандартність, здатність до генерації ідей; 3) застосування до вирішення проблеми різних засобів, методів, пошук їх найкращої комбінації та прогноз змін об’єкта, його динаміки розвитку; 4) формулювання гіпотез, конструювання закономірностей.

Оргдіяльнісні якості проявляються при організації пізнання та творчості, включають в себе: 1) вміння ставити і досягати мети, планувати ді- 
яльність, коригувати етапи діяльності, проводити самоаналіз і самооцінку; 2) здатність взаємодіяти з іншими суб'єктами освіти і навколишнім світом, вміння вести суперечку; 3) здатність організовувати творчість інших, спільне пізнання і генерація ідей. В освітньому процесі слід виявляти і розвивати всі групи якостей, як креативні, так і когнітивні. Особистісні якості виступають орієнтиром при формулюванні освітніх цілей як у глобальному масштабі, так і в приватному, стосовно до досліджуваних дисциплін, спецкурсів, окремих розділів, тем. При навчанні методики викладання питань терапії та гастроентерології розвиваються когнітивні, креативні і оргдіяльнісні якості, що сприяє подальшому інтелектуальному розвитку, індивідуальному сприйняттю навчального процесу і творчому використанню курсантами сучасних способів ведення навчальних занять.

\section{Список літератури}

1. Кан-Калик В. А. Грамматика общения / В. А. КанКалик. - М. : Роспедагентство, 1995. -108 с.

2. Токлаева М. А. Педагогическое общение - важное условие эффективности учебно-воспитательного процесса / М. А. Токлаева // Теория и практика образования в современном мире : материалы III Международной научной конференции (Санкт-Петербург, май 2013 г.) - СПб. : Реноме, 2013. - С. 110-112

3. Лозниця В. С. Основи психології та педагогіки : навч. посіб. / В. С. Лозниця. - М. : КНЕУ, 2001. - 288 с.

4. Столяренко Л. Д. Педагогическая психология : учеб. пособ. / Л. Д. Столяренко. - 5-е изд., исправл. - М. : ЮНИТИ-ДАНА, 2008. -542 с.

5. Прищак М. Д. Психологічні і педагогічні аспекти розвитку духовності / М. Д. Прищак // Вісник Вінницького політехнічного інституту. - 2007. - № 6. C. 133-137.
Висновок. Таким чином, педагогічне спілкування являє собою багатоплановий процес організації, встановлення й розвитку комунікації, заснований на взаєморозумінні і взаємодії між викладачами та учнями, породжуваний єдиними цілями й змістом їхньої спільної діяльності.

У процесі навчання ключову роль відіграють когнітивні та креативні якості особистості як викладачів, так і слухачів курсів удосконалення з терапії та гастроентерології.

Важливою умовою підвищення якості та ефективності навчального процесу є взаємовідносини між викладачем та курсантами, де на перший план виходить авторитет викладача, який базується на професійних, педагогічних та особистісних підвалинах і позитивно впливає на успішність навчання.

Знання особливостей педагогічного спілкування між викладачами та слухачами допоможе викладачам по-новому будувати взаємини з учнями.

6. Ковальчук 3. Я. Педагогічне спілкування як категорія психологічної науки / 3. Я. Ковальчук // Психологічні перспективи. - 2011. - Вип. 18. - С. 121-131.

7. Орбан-Лембрик Л. Е. Соціальна психологія : навч. посіб. / Л. Е. Орбан-Лембрик. - К. : Академвидав, 2005. -448 c.

8. Степанов О. М. Педагогічна психологія: навч. посіб. / О. М. Степанов. - К. : Академвидав, 2011. - 416 с.

9. Прокопець Л. Культура спілкування викладача вищого навчального закладу / Л. Прокопець, Н. М. Мирончук // Модернізація вищої освіти України та за кордоном : зб. наук. пр. / за заг. ред. д-ра. пед. наук, проф. С. С. Вітвицької, канд. пед. наук, доц. Н. М. Мирончук. Житомир : Вид-во ЖДУ І. Франка, 2014. - С. 74-77.

Отримано 08.07.15 